San Jose State University

SJSU ScholarWorks

Master's Theses

Master's Theses and Graduate Research

2003

\title{
Effect of predator management on snowy plovers in Monterey Bay, California
}

Kristina K. Neuman

San Jose State University

Follow this and additional works at: https://scholarworks.sjsu.edu/etd_theses

\section{Recommended Citation}

Neuman, Kristina K., "Effect of predator management on snowy plovers in Monterey Bay, California" (2003). Master's Theses. 2412.

DOI: https://doi.org/10.31979/etd.9xn9-a7hc

https://scholarworks.sjsu.edu/etd_theses/2412

This Thesis is brought to you for free and open access by the Master's Theses and Graduate Research at SJSU ScholarWorks. It has been accepted for inclusion in Master's Theses by an authorized administrator of SJSU ScholarWorks. For more information, please contact scholarworks@sjsu.edu. 


\title{
EFFECT OF PREDATOR MANAGEMENT ON SNOWY PLOVERS IN MONTEREY BAY, CALIFORNIA
}

\author{
A Thesis \\ Presented to
}

The Faculty of the Department of Environmental Studies

San Jose State University

In Partial Fulfillment

of the Requirements for the Degree

Master of Science

by

Kristina K. Neuman

May 2003 
UMI Number: 1415724

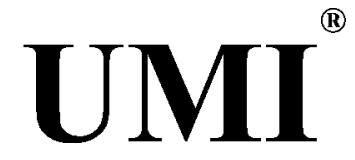

UMI Microform 1415724

Copyright 2003 by ProQuest Information and Learning Company.

All rights reserved. This microform edition is protected against unauthorized copying under Title 17, United States Code.

ProQuest Information and Learning Company 300 North Zeeb Road

P.O. Box 1346

Ann Arbor, MI 48106-1346 
(C) 2003

Kristina Kay Neuman

ALL RIGHTS RESER VED 
1

APPROVED FOR THE DEPARTMENT OF ENVIRONMENTAL STUDIES

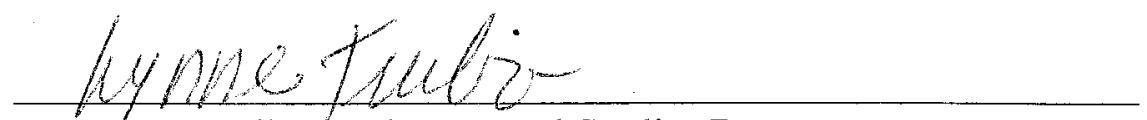

Dr. Lynne Trulio, Environmental Studies Dept.

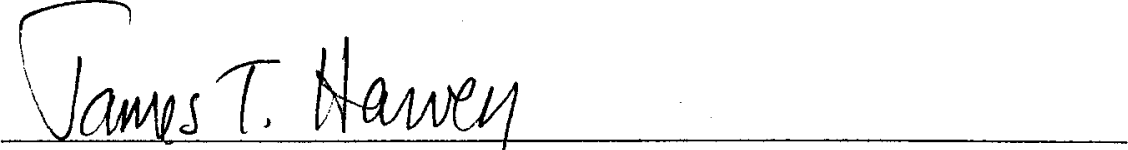

Dr. James T. Harvey, Moss Landing Marine Laboratory



APPROVED FOR THE UNIVERSITY

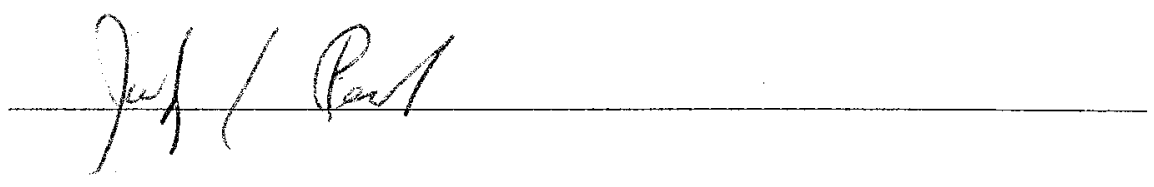




\begin{abstract}
Reproductive success of western snowy plovers (Charadrius alexandrinus) in Monterey Bay, California, was monitored before (1984 to 1990) and after (1991 to 1999) predator management. From 1984 to 1990 , hatch rate decreased from $66 \%$ to $26 \%$ and most nest loss was caused by introduced red fox (Vulpes vulpes regalis). In 1991 and 1992, exclosures were used to protect nests, and from 1993 to 1999, exclosures protected a portion of nests and selected mammalian predators were removed. After predator management, hatching success and number of chicks hatched per male increased and percentage of nests lost to canine predators and to all predator species decreased.

Fledging success, however, decreased and number of chicks fledged per male did not increase. Adult population size did not increase and exclosures increased the probability of abandonment and adult mortality. Fledging success in the final years of this study probably was limited by avian predators.
\end{abstract}




\section{ACKNOWLEDGMENTS}

I gratefully acknowledge the effort of many individuals who gave their time and expertise in reviewing and editing, and guiding the formulation of this thesis. This thesis benefited from the comments of Gary Page, Lynne Stenzel, Lynne Trulio, Jim Harvey, Laird Henkel, and Doug George. I am indebted to other biologists who also conducted this field work including Carleton Eyster, Dave Dixon, Doug George, Laird Henkel, Gary Page, Bernadette Ramer, Lynne Stenzel, and John and Jane Warriner. The inclusion of predator capture data was facilitated by Ivette Loredo at US Fish and Wildlife Service. This research was funded by Point Reyes Bird Observatory, US Fish and Wildlife Service, and the California Department of Parks and Recreation. 


\section{TABLE OF CONTENTS}

LIST OF TABLES vii

LIST OF FIGURES viii

INTRODUCTION

The Global Problem of Alien Predators

BACKGROUND 3

Predator Management

Red Fox Ecology

Snowy Plover Ecology

Regulatory and Management Framework

OBJECTIVES 8

RELATED RESEARCH 9

Dynamics of Small Populations

Ecology of Predators and Prey

Methods of Nest Protection

Problems with Predator Control

METHODS

Study Area

Methods

Analyses

RESULTS 23

Snowy Plover Population Parameters

Mammalian Predators

DISCUSSION 26

Population Stability

Recommendations 


\section{LIST OF TABLES}

Table 1. Causes of failure of snowy plover nests in central Monterey Bay, 1984 1999. 38

Table 2. Annual CPUE and species composition of predators caught in leghold traps in central Monterey Bay, $1993-1999$. 39

Table 3. Annual CPUE and species composition of predators caught in cage traps in central Monterey Bay, $1993-1999$.

Table 4. Renkonen Percentage Similarity Index for annual array of predators caught in leg-hold traps in central Monterey Bay, 1993 -1999. 40 


\section{LIST OF FIGURES}

Figure 1. Study area (larger boxed region), coastal beaches in central Monterey Bay, California.

Figure 2. Number of snowy plover nests and proportion exclosed in central

Monterey Bay, 1984-1999.

Figure 3. Hatch and fledge rate of snowy plovers in central Monterey Bay, 19841999. 43

Figure 4. Number of snowy plover chicks hatched and fledged per male in central Monterey Bay, 1984-1999. 43

Figure 5. Number of breeding adult male and female snowy plovers in central Monterey Bay, 1984-1999. 44

Figure 6. CPUE of red fox and other predators caught in leg-hold traps in central Monterey Bay, 1993-1999. 45

Figure 7. CPUE of red fox and other predators caught in cage traps in central Monterey Bay, 1993-1999. 45

Figure 8. Mean monthly CPUE of red fox caught in leg-hold traps in central Monterey Bay, 1993-1999. 


\section{INTRODUCTION}

\section{The Global Problem of Alien Predators}

In the last two millennia, a global loss of biodiversity has resulted from introduced predators, habitat loss and fragmentation, and other anthropogenic changes in the landscape (Wilson 1999). Worldwide, an estimated $20 \%$ of all modern bird species have been extirpated in the past 2000 years, and of the remaining 9,000 species, $11 \%$ are endangered (Wilson 1999). Introduced predators have been identified as a primary cause of the decline of native avifauna, especially island-nesting seabirds and shorebirds that evolved without adaptations against terrestrial predators (Moors and Atkinson 1984, Burger and Gochfeld 1994, Dowding and Murphy 2001).

Cats (Felis catus), rats (Rattus spp.), and mongoose (Herpestres spp.) introduced by humans have caused significant declines in procellarids and larids on more than fifteen oceanic islands or island groups, including islands in Polynesia, New Zealand, and Alaska (Burger and Gochfeld 1994). Van Aarde (1980) estimated that introduced cats on Marion Island, in the southern Indian Ocean, killed 450,000 seabirds annually. On Kure Atoll, in the Hawaiian Islands, predation by introduced rats prevented Bonin petrels (Pterodroma hypoleuca) from breeding from 1964 to 1968 (Moors and Atkinson 1984). The decline of the dark-rumped petrel (Pterodroma phaeopygia) on the Galapagos Islands has been linked to similar predation impacts caused by introduced rats (Moors and Atkinson 1984). In the northeast Pacific, introduced arctic (Alopex lagopus) and red foxes (Vulpes vulpes) 
that were introduced for fur farming devastated nesting populations of burrow and ground-nesting seabirds (Bailey and Kaiser 1993). Increasingly, control or removal of introduced predators has become a recommended management action for conserving threatened seabirds. Everett and Anderson (1991) recommended immediate removal of feral pigs (Sus scrofa) to protect threatened Townsend's shearwaters (Puffinus auricularis) on Isla Clarion in Baja, California. Burger and Gochfield (1994) recommended the elimination, control, and isolation of alien predators to protect seabirds breeding on islands. Litvinenko (1993) recommended eradication of existing alien predators and prevention of new introductions of alien predators to islands in the northwest Pacific where seabirds breed. Dowding and Murphy (2001) recommended long-term predator control to prevent further declines or the extinction of endemic shorebirds in New Zealand.

Many species of mainland birds are vulnerable to predators because they also nest on the ground, but mainland species differ from island-nesting seabirds in their evolutionary exposure to predators. Island-nesting seabirds have been particularly vulnerable to introduced predators because these predators are "evolutionarily new alien predators" (Burger and Gochfeld 1994); thus, seabirds have not developed behavioral adaptations (e.g. anti-predator displays, selection of inaccessible nest sites) that reduce predation. But many seabirds, such as terns and gulls, and some shorebirds, nest in coastal mainland environments where predators have co-occurred through evolutionary time. Mainlandnesting species, therefore, usually possess behavioral and ecological adaptations to predators that may render them somewhat less vulnerable to predation by alien species 
(Burger and Gochfeld 1994). Predation by introduced and even native species, however, may have cumulative effects on species that have already declined as a result of loss of habitat, habitat fragmentation, and the demographic effects of small populations (Melvin et al. 1991, Hecht and Nickerson 1999, Larson et al. 2002). Conservation efforts to protect coastal mainland species, particularly temperate-nesting terns and plovers, have become increasingly focused on exclusion or removal of introduced predators and some native predators. This research evaluates the effect of predator control on the population size and reproductive success of snowy plovers (Charadrius alexandrinus) in Monterey Bay.

\section{BACKGROUND}

\section{Predator Management}

In the United States, many predator removal programs originated to increase nest success and post-breeding population size of waterfowl and other game birds (Balser et al. 1968, Duebbert and Lokemoen 1980, Beauchamp et al.1996, Côté and Sutherland 1997, Garrettson and Rohwer 2001). In Minnesota, removal of native predators such as red fox (Vulpes fulva) resulted in a $60 \%$ increase in duckling production (Balser et al. 1968). In South Dakota during a three-year period of intensive predator removal on a very large spatial scale $\left(259 \mathrm{~km}^{2}\right)$, nesting success of dabbling ducks approached $100 \%$ (Duebbert and Lokemon 1980). Similarly, Garrettson and Rohwer (2001) found that 
duck nesting success was twice as great at predator removal sites compared with untrapped sites. A meta-analysis of 21 studies of the effect of predator removal on duck nesting success found that predator removal often resulted in greater nesting success (Beauchamp et al.1996). Rates of decline in waterfowl populations, however, were similar between removal and untrapped sites, indicating that long-term decline in waterfowl populations was not the result of predation by native species (Beauchamp et al.1996).

Predator management also has been used to protect declining species of groundnesting birds other than waterfowl. Predator management can involve lethal removal, exclusion, or translocation of target predators. Lethal removal of introduced red foxes (Vulpes vulpes regalis) has increased numbers of California clapper rail breeding in San Francisco Bay (Harding et al. 1998, Harding et al. 2001) and has increased survival rate of endangered malleefowl (Leipoa ocellata) in Australia (Priddel and Wheeler 1997). Exclusion of predators from shorebird nests has been accomplished with individual nest exclosures (Vaske et al. 1994, Estelle et al. 1996, Mabee and Estelle 2000) and with electrified or barrier fencing of nesting areas (Mayer and Ryan 1991). On the U.S. Atlantic coast, piping plover (Charadrius melodus) hatch and fledge rates increased when predator exclosures were placed around individual nests (Rimmer and Deblinger 1990, Melvin et al. 1992). In the Midwestern U.S, reproductive success of piping plovers also increased when electrified fencing protected large nesting areas (Mayer and Ryan 1991). In Scotland, shorebird nesting success increased in areas where hedgehogs were excluded with barrier fencing (Jackson 2001). Translocation of problem predators does not appear 
to have been widely used, probably because of costs in time and equipment, the probability of wide-ranging predators returning to a known food-source, and the problem of introducing new predators (either indigenous or alien) to other environments.

In Monterey Bay, on the central California coast, biologists from Point Reyes Bird Observatory (PRBO) and US Fish and Wildlife Service (USFWS) identified predation by introduced red fox (Vulpes vulpes regalis) as a major factor limiting reproductive success of the western snowy plover (Charadrius alexandrinus; Parker and Takekawa 1993).

Red fox were identified as the major cause of nest loss, and because red fox in California prey on adult shorebirds (Lewis et al. 1993), fox also were suspected as predators of chick and adult plovers at Monterey Bay beaches.

\section{Red Fox Ecology}

Red fox probably were introduced into California from fur farms in the Sacramento Valley in the late 1800 s and early 1900s (Harvey et al. 1992, Jurek 1992). Opportunistic and wide-ranging predators, red fox are successful in a variety of habitat types (Jurek 1992). Feral populations have become established in the Central Valley, San Francisco Bay, Monterey Bay, and southern coastal regions of California (Jurek 1992, Lewis et al. 1993). Because of their adaptable foraging strategies, red fox have been implicated in the decline of some populations of ground-nesting bird species in California, including California least terns (Sterna antilllarum browni), and California clapper rails (Harding et al. 1998, Harding et al. 2001). 
In North America, red foxes generally breed from December through April, with a peak in March (Harding et al. 1998). Foxes live in family groups, consisting of a male, female, and offspring. Territories range in size from 0.45 to $20.8 \mathrm{~km}^{2}$, with the smallest territories occurring in urban areas where fox populations are densest (Trewhella et al. 1988, Zimen 1994, Harding et al. 1998). Red fox may engage in investigative behaviors more commonly at the edge of territories and this behavioral pattern may increase their susceptibility to capture at territory edges (Travaini et al. 1993). Females produce 1-12 young, which disperse from the den in early fall (Zimen 1994) when approximately 6 months old (Harding et al. 1998). Young male red foxes move greater distances than young females (mean $=2.3 \mathrm{~km}$ for males, $0.9 \mathrm{~km}$ for females; Lewis et al. 1993). Other factors affecting dispersal are habitat quality (Voigt and Macdonald 1984, Zimen 1994) and home-range size (Trewhella et al. 1988).

\section{Snowy Plover Ecology}

The western snowy plover is a small, beach-nesting shorebird occurring along the coastline and interior saline flats of western North America (Page et al. 1995). Snowy plovers on the Pacific coast are serially polygamous and capable of raising one to three broods during a nesting season that lasts from March through September (Warriner et al. 1986). The chicks are highly precocial, usually leaving the immediate vicinity of the nest within hours of hatching. Broods are attended by the adult male plover, and are capable of moving great distances $(2-3 \mathrm{~km})$ from the nest (pers. obs.). Nesting habitat consists of sandy ocean beaches and salt pannes that are sparsely vegetated and relatively 
undisturbed by humans. From the late 1970s to 1995 , the coastal California breeding population of the snowy plover declined an estimated $21 \%$ (USFWS 2001). The population faces continued threats from introduced and native predators, habitat alteration, and human disturbance. As a result of the decline and imminent threats to the viability of the population, USFWS listed the Pacific coast population of the western snowy plover as threatened in 1993 (USFWS 1993).

\section{Regulatory and Management Framework}

PRBO has monitored nesting snowy plovers in the Monterey Bay region since 1984 (Page et al. 1999). The first recorded depredation of a snowy plover nest by a red fox in Monterey Bay was at Salinas River National Wildlife Refuge (SRNWR) in 1984, when five nests were taken (Parker and Takekawa 1993). Use of predator exclosures to protect plover nests began in 1991 at SRNWR, when it was documented that recently established red fox were reducing hatching success to low levels (Parker and Takekawa 1993). Predator exclosures were based on those first successfully used by Rimmer and Deblinger (1990) to protect Atlantic coast piping plover (Charadrius melodus) nests.

Lethal control of red fox in Monterey Bay was first considered when evidence indicated that predator exclosures may have increased depredation of adult plovers by providing a focal point for red fox. In addition, soon after hatching, mobile broods of plover chicks left the protection of exclosures with the attending adult plover and were no longer protected from red fox or other mammalian predators. In June 1993, USFWS completed a Predator Management Plan (PMP) and Final Environmental Assessment for 
SRNWR (Parker and Takekawa 1993). The goal of the plan was to increase the abundance and productivity of threatened and endangered bird species and other waterbirds at SRNWR by reducing the number of selected mammalian predators, particularly red fox. Predator removal began in 1993 at SRNWR and in subsequent years the scope of the PMP was expanded to include the adjacent management areas to the north and south of the refuge.

The predator management strategy in the PMP included a combination of existing habitat management programs and a predator removal strategy primarily composed of the use of padded leg-hold traps and cage traps. Padded leg-hold and cage trap methods were selected because they were non-lethal and allowed the release of non-target animals (Parker and Takekawa 1993). Existing habitat management included the continued protection of snowy plover nests with individual nest exclosures and exotic vegetation control in nesting areas.

\section{OBJECTIVES}

From 1984 through 1999 in Monterey Bay, management of predators in snowy plover habitat evolved from no management to active exclusion and removal of nest predators. Throughout this period, nesting snowy plovers were monitored to determine if predator exclosures and red fox removal increased reproductive success and breeding population size. In this study, reproductive success and breeding population size of snowy plovers before (1984 to1990) and after (1991 to 1999) predator management were compared, to 
test the hypothesis that predator management would result in increased reproductive success and breeding population size.

The specific hypotheses of this research, stated in the null form, are as follows.

$\mathrm{H}_{\mathrm{o}}$ : Exclusion and removal of terrestrial predators will not increase hatching success, fledging success, number of chicks hatched per breeding male, or number of chicks fledged per breeding male of snowy plovers in Monterey Bay, California.

$\mathrm{H}_{\mathrm{o} 2}$ : Exclusion and removal of terrestrial predators will not increase the breeding population size of snowy plovers nesting in Monterey Bay, California.

$\mathrm{H}_{\mathrm{o} 3}$ : Exclusion and removal of terrestrial predators will not result in a change in the species composition of the mammalian predator community in Monterey Bay, California.

\section{RELATED RESEARCH}

A variety of predator management programs have been undertaken to increase the size of breeding populations of threatened or declining bird species, yet many factors can limit 
the degree of success. In the following sections, the dynamics of small populations, ecology of predators and prey, predator management methods, and the limitations and potential consequences of predator management are discussed.

\section{Dynamics of Small Populations}

Predation by introduced species may have a cumulative effect on species that have already declined as a result of loss and degradation of habitat (Hecht and Nickerson 1999). Populations that have declined to low levels are less able to withstand population fluctuations resulting from increased predation pressure or natural variability (e.g. a poor reproductive year; Hecht and Nickerson 1999). For declining species, identification of the relative contribution of different life-stages to population stability is essential for understanding the variable impact of different conservation techniques.

A Population Viability Analysis (PVA) for the Pacific Coast population of snowy plovers conducted by PRBO indicated that population stability was most sensitive to changes in adult and juvenile mortality, and secondarily, to annual reproductive rate (Nur et al. 2001). Mortality rates of adult and juvenile shorebirds may be strongly influenced by density-dependent processes on wintering grounds (i.e., food limitation; Baker and Baker 1973, Goss-Custard et al. 2001). Predation, however, is considered a lesser contribution to mortality rate (Baker and Baker 1973). Reducing winter mortality of plovers by increasing food supply, however, is an impractical conservation strategy. Therefore, conservation efforts that reduce mortality of adults and juveniles are one method of benefiting populations. 
Another method of stabilizing or increasing a population is to increase annual reproductive success (i.e., number of juveniles produced; Nur et al. 2001). Côté and Sutherland (1997) argued that increased production of young will not result in a larger adult breeding population because a greater number of juveniles will result in increased density-dependent mortality during winter; the net result is a similar number of juveniles surviving to recruit into the breeding population. For a species that is below historic population size, however, density-dependent processes over winter may be less of a concern until the population approaches carrying capacity. Although the population growth rate of snowy plovers may be most sensitive to changes in adult and juvenile survival, increasing annual reproductive yield is a secondary means of increasing population size (Nur et al. 2001).

\section{Ecology of Predators and Prey}

In an undisturbed ecosystem, the interactions of predators and prey are closely related, and removal of a predator usually will result in an increase in the population size of its primary prey (Wilson and Bossert 1971). When habitats become fragmented and reduced in size, this natural interaction is disrupted. The establishment of nonnative species that out-compete or prey on native species also can disrupt predator-prey relationships.

Many terrestrial ecosystems lack top trophic-level predators because larger predators have been persecuted or are no longer able to access small habitat islands. Larger canids, such as coyotes (Canis latrans) and wolves (C. lupus) are capable of regulating populations of mesopredators via resource competition or by direct predation (Crooks and 
Soulé 1999). Mesopredators are a taxonomically diverse group of mid-sized predators that occupy an intermediate trophic level. Mesopredators, such as foxes (Vulpes spp.), skunks (Mephitis spp.), raccoons (Procyon lotor), badgers (Taxidea taxus), and other mustelids, are typically omnivorous and prey on a wide variety of plant and animal materials. In fragmented or semi-urbanized landscapes, mesopredator populations probably increase as a result of human refuse and physical infrastructure (Melvin et al. 1991).

The natural suppression of mesopredator populations by top trophic-level predators can benefit ground-nesting birds by reducing the risk of clutch predation. Sage-scrub bird diversity in southern California was positively correlated with coyote occurrence and negatively correlated with feral cat occurrence (Crooks and Soulé 1999). Similarly, song sparrow (Melospiza melodia) nesting success in Michigan was positively correlated with coyote abundance and negatively correlated with mesopredator abundance (Rogers and Caro 1998). Thus, populations of prey species that are a food source for mesopredators may be artificially suppressed when mesopredator populations are increased.

In coastal California, common mesopredators include introduced red fox, feral cat, striped skunk (Mephitis mephitis), raccoon, grey fox (Urocyon cinereoargenteus), and Virginia opossum (Didelphis virginianus). Feral cats (domestic cats that have established wild populations) occur throughout California. These cats are omnivorous and surplus hunt (kill prey that they do not eat; Harding et al. 1998). Feral cats have been implicated in reproductive failure in California least terns (Feeney 2000), and are a predator of adult California clapper rails (Albertson 1995). Striped skunks are native to California and 
their populations have increased as a result of human alteration of the landscape (Hecht and Nickerson 1999). Striped skunks are omnivorous, but feed mainly on insects, with small birds and bird eggs making up a relatively small percentage of their diet (Harvey et al. 1992). Despite their small size, skunks can range up to $6.4 \mathrm{~km}$ in one day (Harvey et al. 1992). Raccoons are native to California, but like skunks, have adapted well to urban environments (Hecht and Nickerson 1999). Raccoons are omnivorous and feed regularly on eggs of waterfowl, clapper rails, and other ground-nesting birds (Harvey et al. 1992, Harding et al. 1998). Opossums were introduced from Missouri to San Jose, California in 1900 (Harvey et al. 1992), and are now common throughout coastal California.

Opossums are omnivorous, feeding on plant material, insects, and to a lesser degree, bird eggs. Red foxes, feral cats, raccoons, and opossums are predators of snowy plover eggs, chicks, and adults (Page et al. 1995).

\section{Methods of Nest Protection}

Exclosures and barrier fencing have been widely used to protect various species of shorebirds from mammalian and avian egg predators. On the Atlantic Coast, single nest exclosures have been widely used since 1986 to protect the federally threatened piping plover (Rimmer and Deblinger 1990, Deblinger et al.1992, Melvin et al. 1992). On the Pacific coast, exclosures have been used to protect snowy plover nests (Page et al. 1995, this study) and in the Alaskan arctic, exclosures have been used to protect pectoral sandpiper (Calidris melanotos) nests (Estelle et al.1996). Exclosures also have been used to protect killdeer (Charadrius vociferus) in the Midwest (Mabee and Estelle 2000, 
Johnson and Oring 2002). Electrified barrier fencing also has been widely used to protect plovers (Charadrius spp.) and terns (Sterna spp.) from mammalian predators (Forster 1975, Mayer and Ryan 1991, Koenen et al. 1996, Winton et al. 2000, Jackson 2001). Protecting nests with exclosures has resulted in increased hatching rates for plovers and other shorebirds. In Massachusetts, the hatch rate of piping plover nests that were protected with exclosures was $94 \%$ compared with only $25 \%$ for unprotected nests (Rimmer and Deblinger 1990). In a later study, hatch rate of protected piping plover nests was $90 \%$ compared with $17 \%$ for unprotected nests (Melvin et al. 1992). An analysis of multiple unpublished studies of piping plover hatching success (Deblinger et al. 1992) reported that hatch rate of nests protected with exclosures was $90 \%$. In Alaska, none of the pectoral sandpiper nests protected with exclosures failed as a result of predation (Estelle et al. 1996).

Exclosures are highly effective at increasing hatch rates, but few researchers have monitored fledge rates in response to exclosure use. Melvin et al. (1992) reported that number of chicks fledged per nesting pair of piping plovers increased from 0.60 before exclosure use to 1.41 after exclosure use. Lauro and Tanacredi (2002), however, reported only 0.80 chicks fledged per pair of piping plovers during exclosure use. Following plover chicks until fledging is difficult because shorebird chicks are highly precocial, and usually move away from the immediate nest area within hours of hatching. Causes of chick loss rarely are observed (Lauro and Tanacredi 2002) and suspected causes may not be reported (Melvin et al. 1992). Single-nest exclosures only confer protection to chicks 
within the fenced boundaries; when chicks leave the protection of exclosures, they move into areas where they may be susceptible to mammalian and avian predation.

Barrier fencing is electrified or no-climb fencing that excludes predators from large habitat areas. Exclusionary fencing used over large areas confers more protection than single-nest exclosures to highly mobile plover broods. In North Dakota, nest survival, chick survival, and number of chicks fledged per pair of piping plovers was significantly greater in areas protected by electrified barrier fencing compared with unprotected areas (Mayer and Ryan 1991). In Oklahoma, however, nest success of snowy plovers inside of protected areas was only slightly greater than unprotected areas (Koenen et al. 1996). Problems associated with electrified barrier fencing include continued vulnerability of eggs and chicks to avian predators, intrusion by large mammals, power source failure that renders fences ineffective, accumulation of wind and water-borne debris, and the impracticality of encompassing all potential nesting habitat on an annual basis (Koenen et al. 1996).

\section{Problems with Predator Control}

Although predator control has proven beneficial for waterfowl (Duebbert and Lokemon 1980, Garrettson and Rohwer 2001) and other species of declining birds (Priddel and Wheeler 1997, Harding et al. 2001), removal of one species of predator may result in compensatory predation by another species. In England, control of crows and gulls to improve golden plover (Pluvialis apricaria) nest success resulted in increased depredation of plover nests by native red fox (Parr 1993). In addition, if multiple 
potential predators are not controlled simultaneously, removal of one species may have no discernible effect. For example, in coastal New York, predators were removed to benefit nesting piping plovers, but removal efforts only targeted mammals, not avian nest predators that were present (Lauro and Tanacredi 2002). Subsequent greater levels of egg predation by gulls and crows resulted in no net effect of predator removal on piping plover reproductive success (Lauro and Tanacredi 2002). This research will provide a better picture of the effect of predator management on a rare and declining plover species by examining not only hatch rate and causes of nest loss, but also fledge rate and breeding population size. This study will also examine changes in predator species arrays during predator removal as an indication of how native predators respond to the removal of an introduced predator.

\section{$\underline{\text { Study Area }}$}

\section{METHODS}

Nesting success of snowy plovers was monitored along $18 \mathrm{~km}$ of sandy shoreline in central Monterey Bay on the central California coast (Fig. 1). The northern third of the shoreline was backed by low foredunes and a medium-sized dunefield, the central third by low transverse foredunes and an extensive pickleweed marsh that extended inland along the Salinas River, and the southern third by low foredunes and an extensive dunefield. Snowy plovers primarily nested above the mean high tide line in beach and foredune habitat that was sparsely vegetated with sea rocket (Cakile maritima), beach pea 
(Lathyrus littoralis), beach bur (Ambrosia chamissonis), and American beach grass (Leymus mollis), and at unvegetated to sparsely vegetated sand spits that usually were present on both sides of the Salinas River. In some years, plovers also nested on sandy, emergent islands in the Salinas River approximately $500 \mathrm{~m}$ upstream of the mouth. The northern two-thirds of the shoreline was managed by California State Parks and USFWS and public access was restricted in some locations. The southern third was privately owned but public access was not restricted. Human use was greatest at the extreme northern and southern ends of the study area. Human use was less in the central part of the study area.

\section{Methods}

Nesting success and breeding population size of snowy plovers were monitored from 1984 to 1999. Beginning in 1991, USFWS and California Department of Parks and Recreation used exclosures to protect some nests (Fig. 2). Exclosures were used to protect most nests in 1992 and 1993 , and were gradually phased out over the next 6 years; by 1998, less than $15 \%$ of nests were protected by exclosures (Fig. 2). Exclosure design was based on a method developed by Rimmer and Deblinger (1990) for protecting piping plover nests. Triangular exclosures were constructed of 5 by $10 \mathrm{~cm}$ wire-mesh. Each panel was $7.6 \mathrm{~m}$ long and $1.5 \mathrm{~m}$ high. Panels were attached to stakes with metal clips and then buried to a depth of $20 \mathrm{~cm}$. The top of each panel was bent outward at about a $45^{\circ}$ to discourage predators from climbing into the exclosure. Average exclosure construction time for three people was approximately 30 minutes. Fences constructed of coated wire cable and metal eye-rods also were used to protect some larger nesting areas and 
some individual nests. These "symbolic fences" did not exclude predators but were intended to exclude most human activity. Both exclosures and symbolic fences were posted with signs at appropriate distances from nest locations. Signs contained biological and regulatory language in English and Spanish. From 1993 to 1999, in addition to ongoing use of exclosures, USFWS removed mammalian nest predators, primarily red foxes, feral cats, and striped skunks using a combination of padded leg-hold traps, cage traps, and some shooting. Data for predator removal presented here do not include animals that were shot because they compose a small percentage of total animals captured $(\sim 7 \%)$. The Wildlife Services Division (WSD) of the US Department of Agriculture, conducted predator removal through a cooperative agreement with USFWS.

Most (> 80\%) banded plovers nesting in the study area had been marked as chicks with unique three- or four-color combinations. Unbanded adults that recruited into the study area also were trapped and banded. One or both adults were banded on at least $93 \%$ of the nests, with both adults banded at greater than $75 \%$ of nests. When population size is presented, breeding adults that nested multiple times in the same area were counted only once.

Every nest within the study area was located and visited as frequently as necessary to track and account for the activities of each breeding pair. For most nests, the visit rate was 3 to 4 times per week, but at some locations as infrequently as once a week or as frequently as daily. A nesting attempt was defined as a clutch of eggs that was incubated until it hatched, was determined to be non-viable, was abandoned due to the death or desertion of an adult, was depredated by a predator, or was destroyed by environmental or human causes. One-egg clutches that were never incubated were not counted as nesting 
attempts. For incomplete clutches, hatch dates were estimated from egg-laying dates. Incubation length of snowy plovers is approximately 28 days from clutch completion and completion of a clutch from initiation takes 3 to 5 days (Page et al. 1995). So a clutch found as 2 eggs, for example, would be expected to hatch in 28 to 33 days. For complete clutches, eggs were manually floated in water to determine the degree of development of the embryo (see Hays and Lecroy 1971). Once a nested was located it was checked from afar (distance dependent on local topography but appropriate to avoid flushing incubating birds from nests) for the presence of an incubating adult and, if an adult was absent, approached to check nest contents, until shortly before estimated hatch. Precise hatch dates were determined by examining eggs for cracks, tapping sounds, and chicks peeping as the estimated hatch date approached. Newly hatched chicks were captured at or near the nest within hours of hatching and banded with a unique three- or four-color combination. Broods were monitored by directly observing chicks or adult display behaviors throughout the chick-rearing period until fledging ( 28 days of age). Adult display behaviors that indicated the existence of a brood included vocalizing, distraction displays (running, tail-dragging, and broken wing displays) and agitated flying in the vicinity of the brood. All snowy plover monitoring and banding were conducted under USFWS Endangered Species Permit TE-807078-2 and federal banding permit (09316DB).

Five measures of snowy plover breeding success were examined: hatch rate, number of chicks hatched per breeding male, fledge rate, number of chicks fledged per breeding male, and number of breeding adults. Hatch rate was defined as the percentage of clutches where at least one egg 
hatched. Fledge rate was defined as the percentage of chicks surviving to 28 days or more (Page et al. 1995). The ratio of the number of chicks hatched and fledged per breeding male were calculated because males rear the chicks and are more site faithful within and among years than females (Page et al. 1995).

Causes of nest loss were determined by examining the nest scrape for predator tracks, eggshell fragments, and partially depredated chicks or adults. Predation was categorized as canine predation (red fox, grey fox, domestic dog, and unknown canid), and non-canine predation. Noncanine predation included striped skunk, trampling by gulls (Larus spp.) or California brown pelicans (Pelecanus occidentalis), depredation of hatching eggs by American kestrel (Falco sparverius) or loggerhead shrike (Lanius ludovicianus), and unknown predator. Other causes of nest loss included environmental factors (wind and tide), losses attributable to human activities (crushing of eggs by pedestrians, equestrians, and vehicles; deliberate vandalism of nests; and collection of eggs by researchers), nest desertion (not caused by disappearance of a nesting adult), and non-viability of eggs in clutches. Because most nesting adults were banded, nest desertion accompanied by the disappearance and presumed death of one nesting adult was detectable and was categorized separately from nest desertion without evidence of adult loss. Causes of chick loss rarely were observed.

\section{Analyses}

Annual reproductive measures and breeding population size during pre-management (1984 1990) and management phases (1991-1999) were compared. During the pre-management phase, exclosures were not used and predators were not removed. During the first part of the 
management phase (from 1991 to 1993) nests were protected with exclosures. After 1993, exclosure use continued and selected predators were removed. Hatch rate, fledge rate, number of chicks hatched per breeding male, and number of chicks fledged per breeding male were compared using two-tailed Student's t-Tests $(\alpha=0.05)$. The number of breeding adult males and females also were compared between phases using a two-tailed Student's t-test but alpha was set at 0.10 to minimize the possibility of making a Type $\amalg$ error. To determine the effectiveness of exclosure use and predator removal, the mean percentage of nests depredated by canids and percentage depredated by all predators were compared between phases using one-tailed Student's t-Tests $(\alpha=0.05)$. Although not all nests were exclosed during the management phase, the effect of exclosure use on rate of nest abandonment was compared between phases. The mean percentage of all nests initiated that were lost as result of both types of abandonment (abandonment without adult mortality and abandonment accompanied by presumed mortality) was compared between phases using a one-tailed Student's t-Test $(\alpha=0.05)$. The mean percentage of nest abandonment accompanied by the mortality of an adult also was compared between phases using a one-tailed Student's t-Test $(\alpha=0.05)$. Reproductive rates for exclosed and unexclosed nests during the management phase were not compared because nests that were most vulnerable to predators were protected (e.g. located in an area with obvious predator activity).

The relative abundances of predators during the management phase were compared by calculating annual catch-per-unit effort (CPUE) for red fox and other prerdators (feral cat, skunk, opossum, raccoon, grey fox, and unidentified predator). CPUE was used as a proxy of predator abundance because it is a measure of abundance that is standardized by 
trapping effort (number of animals caught divided by number of traps deployed). The majority (91\% of animals caught in padded leg-hold traps and $95 \%$ of those caught in cage traps) of non-target predators (e.g. grey fox, raccoon, opossum) were released into the environment. To examine within season (March to September) trends in red fox abundance, mean monthly CPUE of red fox caught in leg-hold traps was calculated. To examine maximum differences in predator species composition among years, a Renkonen percentage similarity index (Krebs 1999) was used to compare the array of predator species caught in leg-hold traps each year of predator management with the array captured in all other years. The Renkonen Index was calculated as:

$$
\begin{aligned}
& P=\sum_{i} \operatorname{minimum}\left(p_{1 i}, p_{2 i}\right) \\
\text { where } \mathrm{P} & =\text { Percentage similarity between sample } 1 \text { and } 2 \\
\mathrm{P}_{1 i} & =\text { Percentage of species } i \text { in community sample } 1 \\
\mathrm{P}_{2 i} & =\text { Percentage of species } i \text { in community sample } 2
\end{aligned}
$$

The Renkonen Index was calculated from percentages of animals caught in leg-hold traps because most red fox were caught in leg-hold traps. Index values closest to $0 \%$ are least similar. For this study, the area of biological interest is in differences, not similarities, between annual predator species arrays. Therefore, values of less than $30 \%$ similarity were assumed biologically significant (Krebs 1999). Annual values for species composition for both capture methods also are presented. 


\section{RESULTS}

\section{Snowy Plover Population Parameters}

In the pre-management phase (1984-1990), 728 plover nests were monitored and 682 nests were monitored in the management phase (1991-1999). During the management phase, $48.8 \%$ of nests $(n=333)$ were protected with exclosures (Fig. 2). From the premanagement to management phase, mean hatch rate increased significantly from $42.6 \%$ $(\mathrm{SD}=12.4 \%)$ to $67.7 \%(\mathrm{SD}=12.2 \% ; P<0.001)$, but mean fledge rate decreased significantly from $42.2 \%(\mathrm{SD}=6.3 \%)$ to $29.9 \%(\mathrm{SD}=11.5 \% ; P=0.012$; Fig. 3$)$. The number of chicks hatched per breeding male significantly increased from $2.0(\mathrm{SD}=0.49)$ in the pre-management phase to 2.7 ( $\mathrm{SD}=0.34 ; P=0.002$; Fig. 4) in the management phase. The number of chicks fledged per male averaged $0.86(\mathrm{SD}=0.28)$ during the premanagement phase and $0.81(\mathrm{SD}=0.29 ; P=0.351 ; \mathrm{Fig} .4)$ during the management phase. From the pre-management to management phase, the mean number of breeding males appeared to decrease from $55.4(\mathrm{SD}=12.5)$ to $47.7(\mathrm{SD}=8.99)$ but this decline was not significant $(P=0.17$; Fig. 5 ). The mean number of females decreased from 57.7 $(\mathrm{SD}=11.8)$ to $49.0(\mathrm{SD}=11.8)$ between the two phases but this decrease also was not significant $(P=0.16 ;$ Fig. 5$)$.

The mean percentage of failed nests attributed to predators declined from $52.3 \%$ (SD = $8.7 \%$ ) in the pre-management phase to $35.6 \%$ ( $\mathrm{SD}=17.3 \% ; P=0.017)$ during the management phase, indicating that predators were responsible for a significantly greater 
proportion of nest losses before management (Table 1$) .72 .6 \%(\mathrm{SD}=27.2 \%)$ of predator losses were caused by canids during the pre-management phase but the percentage attributed to canids decreased to $32.4 \%(\mathrm{SD}=34.6 \% ; P=0.012)$ during the management phase (Table 1). Other identified causes of nest loss (for all years combined) included humans $(10 \%)$, environmental factors $(10 \%)$, nest abandonment $(5 \%)$, and non-viable clutches $(2 \%$; Table 1$)$.

The rate of nest abandonment increased slightly but significantly, from $3.7 \%$ (SD = $1.5 \%)$ to $7.8 \%(\mathrm{SD}=0.9 \%)$, during the management phase $(P=0.03)$. The rate of nest abandonment accompanied by the mortality of an adult also significantly increased, from $0.8 \%(\mathrm{SD}=5 \%)$ to $4 \%(\mathrm{SD}=4 \% ; P=0.03)$. During the management phase, $49 \%$ of all nests were exclosed, but $76 \%$ of the 25 adult plovers that disappeared during incubation and were presumed dead were nesting in exclosures. The number of mortalities in exclosures is greater than would be expected by chance $\left(\chi^{2}=7.021, P<0.01\right)$. In most years, the causes of mortality of adults nesting in exclosures were unknown, but in 1997 avian predation of adult plovers at nests was documented. During a 12-day period in April 1997, a merlin (Falco columbus) was observed depredating one adult and suspected of depredating eight others nesting in exclosures.

\section{$\underline{\text { Mammalian Predators }}$}

CPUE of red fox caught in padded leg-hold traps was greatest in the first year of predator removal and markedly decreased thereafter (Fig.6). CPUE of all other predator species combined was initially low and varied in the years after predator removal began 
(Fig. 6). CPUE of red fox caught in cages was low in every year, whereas CPUE of all other predator species combined peaked in 1994 and generally declined throughout the remainder of the removal period (Fig.7). Other than red fox, the primary predators captured in both types of traps were feral cat, skunk, and opossum (Tables 2 and 3). Capture rate of red fox caught in leg-hold traps was greatest in the late summer, during juvenile dispersal (Fig. 8). Because most fox were caught at the end of the plover nesting season, CPUE was not directly compared to plover reproductive parameters within the same year.

Maximum differences in PSI values (<30\% similarity) occurred only between 1993 and subsequent years. The array of predators captured in 1993 differed most from the arrays captured in 1995, 1996, 1997, and differed to a lesser degree from the array caught in 1998 (Table 4). These differences in predator species arrays were caused by the large percentage of red fox captured in 1993 (83\% of all predators) compared with the small percentages captured in $1995(7 \%), 1996(9 \%), 1997(9 \%)$, and 1998 (16\%; Table 1). In contrast, 1993 was similar to 1994 and somewhat similar to 1999 (Table 4). These similarities were caused by similarly large percentages of red fox captured in 1994 (58\%) and 1999 (52\%) compared with 1993 (83\%; Table 2). Predator arrays captured in 1994 and 1999, in 1997 and 1998, and in 1997 and 1995 also were similar (Table 4). 


\section{DISCUSSION}

Most research on predator control monitors the effect of exclusion or removal of predators on nest predation rates. Few researchers have examined the effect of management on fledge rate or breeding population size. In this study, analyses of nest predation, fledge rate, and breeding population size present a more detailed picture of the effect of predator control. Studies at other locations have shown that use of exclosures reduced the probability of nest predation (Deblinger et al. 1992, Melvin et al. 1992, Estelle et al. 1996, Johnson and Oring 2002). Results of this study also show that exclosures prevented red fox and other nest predators from depredating snowy plover eggs. Before exclosures were used, the hatch rate of snowy plover nests in Monterey Bay was less than it was after 1991, the first year of exclosure use (Fig 3). When nest predators were removed beginning in 1993, and use of nest exclosures gradually eliminated (Fig. 2), hatch rate remained high, and a significant shift in the primary cause of nest loss occurred. Predators, particularly canids, caused the majority of nest losses before predator removal, but after removal efforts, nest losses primarily were attributed to other factors, such as human activities and environmental factors. Maintenance of a high hatch rate and reduced nest predation by canids indicated that abundance of the primary egg predators in the study area was significantly reduced during the management phase. An alternative explanation, that predators avoided traps and were still abundant in the study area, was not supported by the increased hatch rate. 
Although hatch rate increased with predator management, fledge rate decreased. It is probable that different factors affected hatching and fledging success. The average fledge rate before exclosure use and predator removal was comparable with rates reported by Warriner et al. (1986) and Page et al. (1995), but average fledge rates during the management phase was significantly less. Before predator removal began, use of exclosures in 1991 and 1992 allowed large numbers of chicks to hatch into an environment where red fox probably were abundant. Relatively low fledge rates during these two years (Fig. 3) may indicate that red fox were the primary cause of chick mortality that occurred when highly precocial chicks vacated the protection of exclosures. Furthermore, fledge rate increased during the first three years of predator removal (1993 to 1995$)$. By 1995 , fledge rate was at the second highest level recorded during the 15 year study. From 1994 to 1995 , the percentage of red fox captured dropped from $57 \%$ of all predators to $9 \%$ (Table 2). During this early period of predator removal, markedly lower abundance of red fox initially may have resulted in greater fledging success. Fledge rate, however, declined after 1995, and except for a slight rebound in 1998 never approached either pre-management or 1995 levels for the remaining years. This decline probably resulted from increased predatory pressure from avian predators.

In the later years of this study, depredation of plover chicks by avian predators, especially northern harriers, American kestrels, or loggerhead shrikes, was identified as a probable factor affecting fledging success at one or more beach sections from 1994 onwards. In 1994, lesser late-season fledging success at one beach area corresponded with the presence of hunting American kestrels and loggerhead shrikes. In 1996, a shrike 
was seen taking a newly hatched chick from an exclosure at SRNWR. In 1998 and 1999, a pair of northern harriers nesting in the marsh at SRNWR was seen hunting over the dunes where broods subsequently disappeared.

Increased abundance of avian predators in the study area in the later years of the management period may have been linked to decreased red fox abundance. Removal of red fox may have led to increased nest success of northern harrier, a ground-nesting raptor that probably hatched few chicks in the study area before fox were removed.

Additionally, red fox undoubtedly were preying on other species in addition to harrier nests, including small mammals; after fox removal small prey species were probably more abundant in the dunes and upper beach areas. When red fox abundance was reduced, nesting harriers, kestrels, and shrikes may have responded to greater densities of plover chicks and other small animals in the dunes and upper beach as a prey resource. Such compensatory and density-related predation have been reported in other studies of shorebird hatching success (Page et al. 1983, Parr 1993). These results support the possibility of compensatory and density-related predation of snowy plover chicks by avian predators. An alternative hypothesis, that mammal predators other than red fox were preying on chicks, is not supported by the stable (leg-hold trap) and declining (cage trap) trends in CPUE of these mammal species.

Snowy plovers that nested in single-nest exclosures were subject to greater mortality than adults nesting outside of exclosures. Other researchers have found that exclosures attract mammalian predators to nest sites, resulting in mortality of incubating plovers (Nol and Brooks 1982, Johnson and Oring 2002). In Monterey Bay, avian predators, such 
as merlin, shrike, American kestrel, and great horned owl (Bubo virginianus), may have learned to locate incubating snowy plovers within exclosures. At Point Reyes National Seashore, unidentified predatory birds depredated snowy plovers nesting in exclosures that had tops (PRBO unpubl. data), and in this study, merlin were observed perching on exclosures, with remains of nesting plovers (identifiable to nest by USFWS band) found nearby.

\section{Population Stability}

Persistently low numbers of chicks fledged per breeding adult may eventually cause a decline in breeding population size. In this study, a significantly lesser fledge rate during the management phase did not result in a decrease in number of breeding plovers in the study area or in the number of chicks fledged per breeding male. Although adult population size did not decrease significantly between phases, the mean number of chicks fledged per male per year was below the estimated 1.0 necessary for population stability (USFWS 2001) in both phases. If current fledging rates persist, population decline eventually may occur. In this study, fledging rate was initially limited by red fox predation of nests and later probably limited by avian predation of chicks. Future management strategies to increase fledge rate of snowy plovers should be targeted at mitigating or removing these limiting factors.

Most studies of the effects of exclosure use on reproductive success of plovers do not distinguish between nest loss from abandonment caused by exclosure installation and nest loss resulting from adult mortality (Melvin et al.1992, Mabee and Estelle 2000), unless 
predation of incubating plovers is directly observed (e.g. Nol and Brooks 1982, Johnson and Oring 2002). It is therefore possible that some nest abandonment previously reported in exclosure studies was caused by adult mortality associated with the presence of exclosures themselves when it was attributed to variable installation time, or design specifications. Because PVAs for both snowy and piping plover have demonstrated that population growth rate is most sensitive to changes adult survival (Nur et al. 2001, Larson et al. 2002), caution regarding the effect of exclosures on annual adult survival is warranted. The population level consequences of reduced adult survival should be carefully considered before widespread use of exclosures is initiated, especially for already declining species (Johnson and Oring 2002).

Although not statistically significant, the breeding population size of snowy plovers may have decreased during the management phase of this study. As previously mentioned, the population stability of snowy plovers is most influenced by changes in adult survivorship (Nur et al. 2001). In the PVA for snowy plovers, population decline is predicted to occur under "status quo" conditions (Nur et al. 2001). In Monterey Bay, the conditions of status quo included intensive conservation management from 1991 through 1999 with no measurable increase in breeding population size. This trend is troubling and indicates that conservation efforts directed at population recovery must test and refine new, more effective management techniques. 


\section{$\underline{\text { Recommendations }}$}

In this study, a combination of exclosure use and mammalian predator removal was highly effective at increasing hatching rate of snowy plovers that had been heavily impacted by red fox predation. As exclosure use was discontinued, predator removal ensured the persistence of a high hatch rate. Foxes, however, were not the only potential chick predators in the area, and as foxes were removed, other predator populations probably increased or shifted to the dunes and beach, resulting in a decrease in fledge rate. Larson et al. (2002) suggested that a combination of individual nest exclosures and barrier fencing may increase fledging success of piping plovers up to $44 \%$ and expanded use of exclosures may cause a significant increase in population size. This study suggests that a more cautious use of individual nest exclosures may be warranted. The evidence presented here demonstrates that widespread use of exclosures may cause greater mortality of adult shorebirds nesting within exclosures, and that exclosures may not necessarily achieve a significant increase breeding population size. Although use of exclosures may significantly improve hatching success, exclosures should be used temporarily, sparingly, and in combination with predator management. Predator management clearly must consider the full suite of species that impact the eggs and chicks of a protected species, and continually monitor and adapt to changes in the predator composition of an area. Based on the previous analysis, the following management recommendations are suggested for conservation of snowy plovers in the Monterey Bay area. 
1) Use exclosures to protect plover nests only when no other management strategy may prevent nest loss. Prohibit use of exclosures during early (March and April) and late (July through September) raptor migration periods to minimize mortality of adult plovers.

2) Continue mammalian predator removal to maintain hatch rate of snowy plovers above $60 \%$.

3) Where feasible, remove all human infrastructure (e.g., fence-lines, non-indigenous tree species) that attract avian predators to coastal dune habitats that, normally, they would not occupy.

4) Monitor impacts of avian predators on snowy plover chicks by focused observation of predator activity.

5) Consider experimental translocation of avian predators that locally reduce snowy plover fledging.

6) Monitor the effects of avian predator removal on fledging success of snowy plovers. 


\section{REFERENCES CITED}

Albertson, J. 1995. Ecology of the California clapper rail in South San Francisco Bay. M.A. Thesis. San Francisco State University, San Francisco, CA.

Bailey, E. and G.W. Kaiser. 1993. Impacts of introduced predators on nesting seabirds in the northeast Pacific. In Vermeer, K. Briggs, K.T., Morgan, K.H., and SiegelCausey, D. eds. The status, ecology, and conservation of marine birds of the North Pacific. Canadian Wildlife Service Special Publication, Ottawa.

Baker, M.C. and A.E.M. Baker. 1973. Niche relationships among six species of shorebirds on their wintering and breeding ranges. Ecological Monographs 43:193-212.

Balser, D.S., H.H. Dill, and H.K. Nelson. 1968. Effect of predator reduction on waterfowl nesting success. Journal of Wildlife Management 32(4):669-682.

Burger, J., and M. Gochfield.1994. Predation and effects of humans on island-nesting seabirds. Pp. 39-67. In Seabirds on Islands: Threats, Case-studies, and Action Plans. D. Nettleship, J. Burger, M. Gochfield, eds. Birdlife International, Cambridge, England.

Côté, I.M. and W.J. Sutherland. 1997. The effectiveness of removing predators to protect bird populations. Conservation Biology 11(2):395-405.

Crooks, K.R. and M.E. Soulé. 1999. Mesopredator release and avifaunal extinctions in a fragmented system. Nature 400:563-566.

Deblinger, R.D., J.J. Vaske, and D.W. Rimmer. 1992. An evaluation of different predator exclosures used to protect Atlantic coast piping plover nests. Wildlife Society Bulletin 20:274-279.

Dowding J.E. and E.C. Murphy. The impact of predation by introduced mammals on endemic shorebirds in New Zealand: a conservation perspective. Biological Conservation 99:47-64.

Duebbert, H.F. and J.T. Lokemoen. 1980. High duck nesting success in a predatorreduced environment. Journal of Wildlife Management 44(2):428-437. 
Estelle, V.B., T.B. Mabee, and A.H. Farmer. 1996. Effectiveness of predator exclosures for pectoral sandpiper nests in Alaska. Journal of Field Ornithology 67(3):447452.

Everett, W.T. and D.W. Anderson. 1991. Status and conservation of the breeding seabirds on offshore Pacific islands of Baja California and the Gulf of California. International Council for Bird Preservation Technical Publication No. 11:115-139.

Feeney, L. 2000. California Least Tern (Sterna antillarum browni) In Goals Project. Baylands Ecosystem Species and Community Profiles: Life Histories and environmental requirements of key plants, fish and wildlife. Prepared by the San Francisco Bay Area Wetlands Ecosystem Goals Project. P.R. Olofson, editor. San Francisco Regional Water Quality Control Board.

Forster, J.A. 1975. Electric fencing to protect sandwich terns against foxes. Biological Conservation $7: 85$.

Goss-Custard, J.D., A.D. West, R.A. Stillman, S.E.A.L.V. Dit Durell, R.W.G. Caldow, S. McGrorty and R Nagarajan, 2001. Density-dependent starvation in a vertebrate without significant depletion. Journal of Animal Ecology 70:955-965.

Harding, E.K., D.F. Doak, J. Albertson, and J.E. Takekawa. 1998. Predator management in San Francisco Bay wetlands: past trends and future strategies. Unpublished Report, USFWS, Newark, CA.

Harding, E.K., D.F. Doak, and J. Albertson. 2001. Evaluating the effectiveness of predator control: the non-native red fox as a case study. Conservation Biology 15(4):1114-1122.

Harvey, T.E., K.J. Miller, R.L. Hothem, M.J. Rauzon, G.W. Page, and R.A. Keck. 1992. Status and trends report on wildlife of the San Francisco Estuary. San Francisco Estuary Project/ USFWS, Sacramento, CA.

Hays, H. and M. LeCroy. 1971. Field criteria for determining incubation stage of the Common tern. Wilson Bulletin 83:425-429.

Hecht, A. and P.R. Nickerson. 1999. The need for predator management in conservation of some vulnerable species. Endangered Species Update. 16(6):114-118.

Jackson, D.B. 2001. Experimental removal of introduced hedgehogs improves wader nest success in the Western Isles, Scotland. Journal of Applied Ecology 38:802812. 
Johnson, M. and L.W. Oring. 2002. Are nest exclosures an effective tool in plover conservation? Waterbirds 25:184-190.

Jurek, R.M. 1992. Nonnative red foxes in California. State of California. The Resources Agency. Department of Fish and Game Nongame Bird and Mammal Section Report, 92-04.

Krebs, C.J. 1999. Ecological Methodology. Second Edition. Menlo Park, CA: Benjamin/Cummings.

Koenen, M.T., R.B. Utych, and D.M. Leslie, Jr. 1996. Methods used to improve least tern and snowy plover nesting success on alkaline flats. Journal of Field Ornithology 67(2):281-291.

Larson, M.A., M.R. Ryan, and R.K. Murphy. 2002. Population viability of piping plovers: effects of predator exclosures. Journal of Wildlife Management 66(2):361-371.

Lauro, B. and J. Tanacredi. 2002. An examination of predatory pressures on piping plovers nesting at Breezy Point, New York. Waterbirds 25(4): 401-409.

Lewis, J.C., K.L. Salee, and R.T. Golightly. 1993. Introduced red fox in California. Nongame Bird and Mammal Section Report 93-10. California Department of Fish and Game, Sacramento, CA.

Litvinenko, N.M. 1993. Effects of disturbance by people and introduced predators on seabirds in the northwest Pacific. In Vermeer, K. Briggs, K.T., Morgan, K.H., and Siegel-Causey, D. eds. The status, ecology, and conservation of marine birds of the North Pacific. Canadian Wildlife Service Special Publication, Ottawa.

Mabee, T.J. and V.B Estelle. 2000. Assessing the effectiveness of predator exclosures for plovers. Wilson Bulletin 112(1):14-20.

Mayer, P.M. and M.R. Ryan. 1991. Electric fences reduce mammalian predation on nests and chicks. Wildlife Society Bulletin 19:59-63.

Melvin, S.M., L.H. MacIvor, and C.R. Griffin. 1992. Predator exclosures: A technique to reduce predation at piping plover nests. Wildlife Society Bulletin 20:143-148.

Moors, P.J. and I.A.E. Atkinson. 1984. Predation on seabirds by introduced animals, and factors affecting its severity. International Council for Bird Preservation Technical Publication No. 2:667-690 
Nol, E. and R.J. Brooks. 1982. Effects of predator exclosures on nesting success of killdeer. Journal of Field Ornithology 53(1):263-268.

Nur, N., G.W. Page, and L.E. Stenzel. 2001. Population Viability Analysis for Pacific coast snowy plovers. Appendix D, 40pp In Western Snowy Plover (Charadrius alexandrinus nivosus) Pacific Coast Population Draft Recovery Plan. USFWS, Portland, Oregon, xix $+630 \mathrm{pp}$.

Page, G.W., L.E. Stenzel, D.W. Winkler, and C.W. Swarth. 1983. Spacing out at Mono Lake: breeding success, nest density, and predation in snowy plover. Auk 100:13-24.

Page, G.W, J.S. Warriner, J.C. Warriner, and P.W.C. Patton. 1995. Snowy Plover (Charadrius alexandrinus). In The Birds of North America, No. 154 (A. Poole and F. Gill, eds.). The Academy of Natural Sciences, Philadelphia, PA, and the American Ornithologists' Union, Washington, D.C.

Parker, M.W., and J.E. Takekawa. 1993. Salinas River National Wildlife Refuge Predator Management Plan and Final Environmental Assessment. Unpublished Report, USFWS, Newark, CA.

Parr, R. 1993. Nest predation and numbers of Golden Plovers (Pluvialis apricaria) and other moorland waders. Bird Study 40:223-231.

Priddel, D. and R. Wheeler. 1997.Efficacy of fox control in reducing the mortality of released captive-reared malleefowl, Leipoa ocellata. Wildlife Research 24:469482 .

Rimmer, D. W., and R.D. Deblinger. 1990. Use of predator exclosures to protect piping plover nests. Journal of Field Ornithology 61(2):217-223.

Rogers, C.M. and M.J. Caro. 1998. Song sparrows, top carnivores and nest predation: a test of the mesopredator release hypothesis. Oecologia 116:227-233.

Travaini, A., J. Aldama, and M. Delibes. 1993. Red fox capture locations in relation to home range boundaries. Mammalia. 59(3):455-459.

Trewhella, W.J., S. Harris, and F.E. McAllister. 1988. Dispersal distance, home-range size and population density in the red fox (Vulpes vulpes): a quantitative analysis. Journal of Applied Ecology 25(2):423-434 
USFWS. 1993. Endangered and threatened wildlife and plants; determination of threatened status for the Pacific coast population of the western snowy plover; final rule. Federal Register 58 (42): 12864-12874.

USFWS. 2001. Western Snowy Plover (Charadrius alexandrinus nivosus) Pacific Coast Population Draft Recovery Plan, Portland, Oregon.

van Aarde, R. J. 1980. The diet and feeding behavior of feral cats, Felis catus at Marion Island. South African Journal of Wildlife Research 10(3/4): 123-128

Vaske, J.J., D.W. Rimmer, and R.D. Deblinger. 1994. The impact of different predator exclosures on piping plover nest abandonment. Journal of Field Ornithology 65(2):201-209.

Voigt, D.R. and D.W. Macdonald. 1984. Variation in the spatial and social behavior of the red fox, Vulpes vulpes. Acta Zoologica Fennica 171:261-265.

Warriner, J.S., J.C. Warriner, G.W. Page, and L.E. Stenzel. 1986. Mating system and reproductive success of a small population of polygamous Snowy Plovers. Wilson Bulletin 98:15-37.

Wilson, E.O. 1999. The Diversity of Life. New York: W. W. Norton and Co., Inc.

Wilson, E.O. and W.H. Bossert. 1971. A Primer of Population Biology. Sunderland, MA: Sinauer Assoc. Inc.

Winton, B.R. and D.M. Leslie, Jr. 2000. Breeding ecology and management of snowy plovers an north-central Oklahoma. Journal of Field. Ornithology 71(4):573-584.

Zimen, E. 1984. Long range movements of the red fox, Vulpes vulpes. L. Acta Zoologica Fennica 171:267-270. 


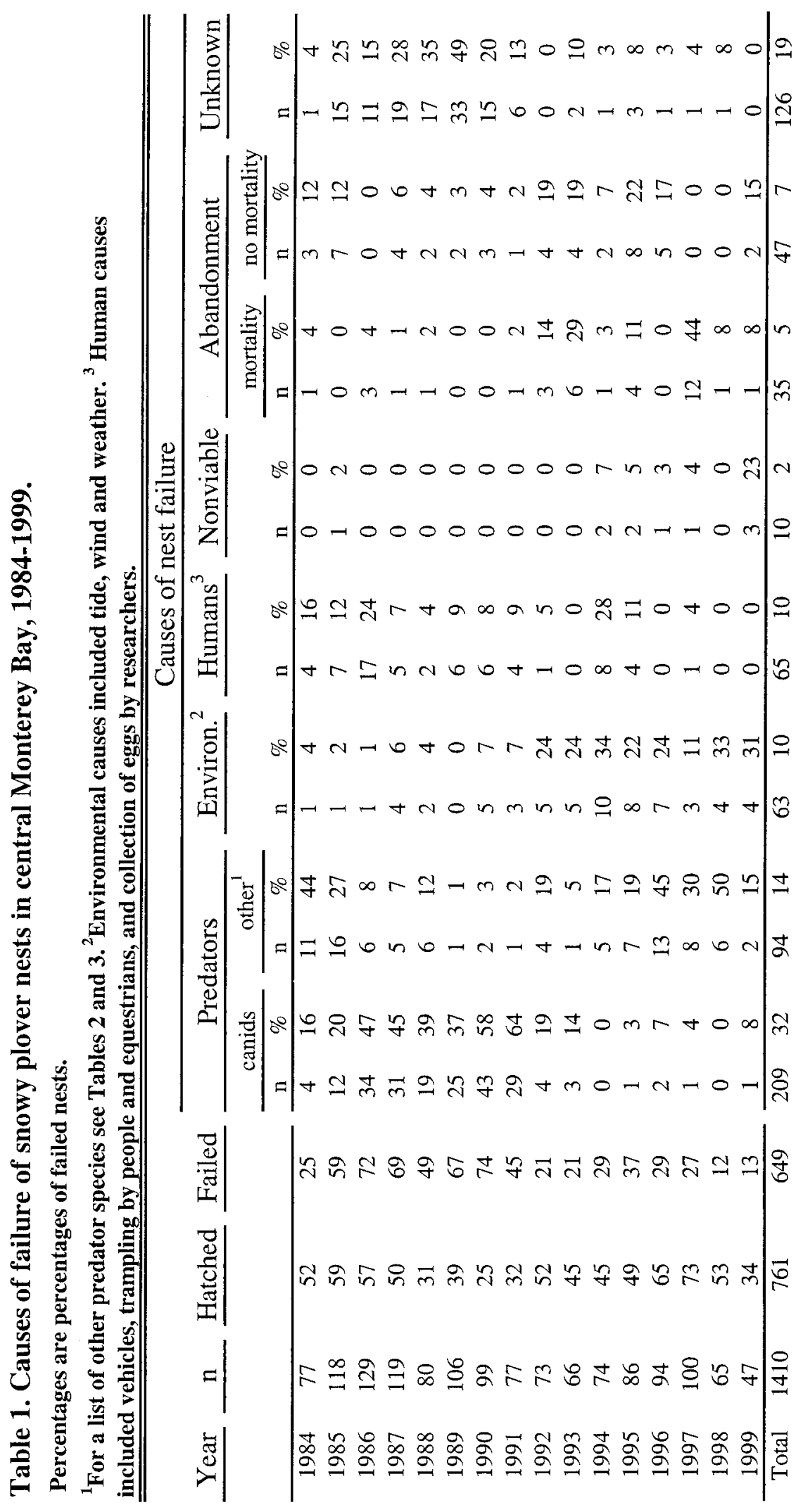




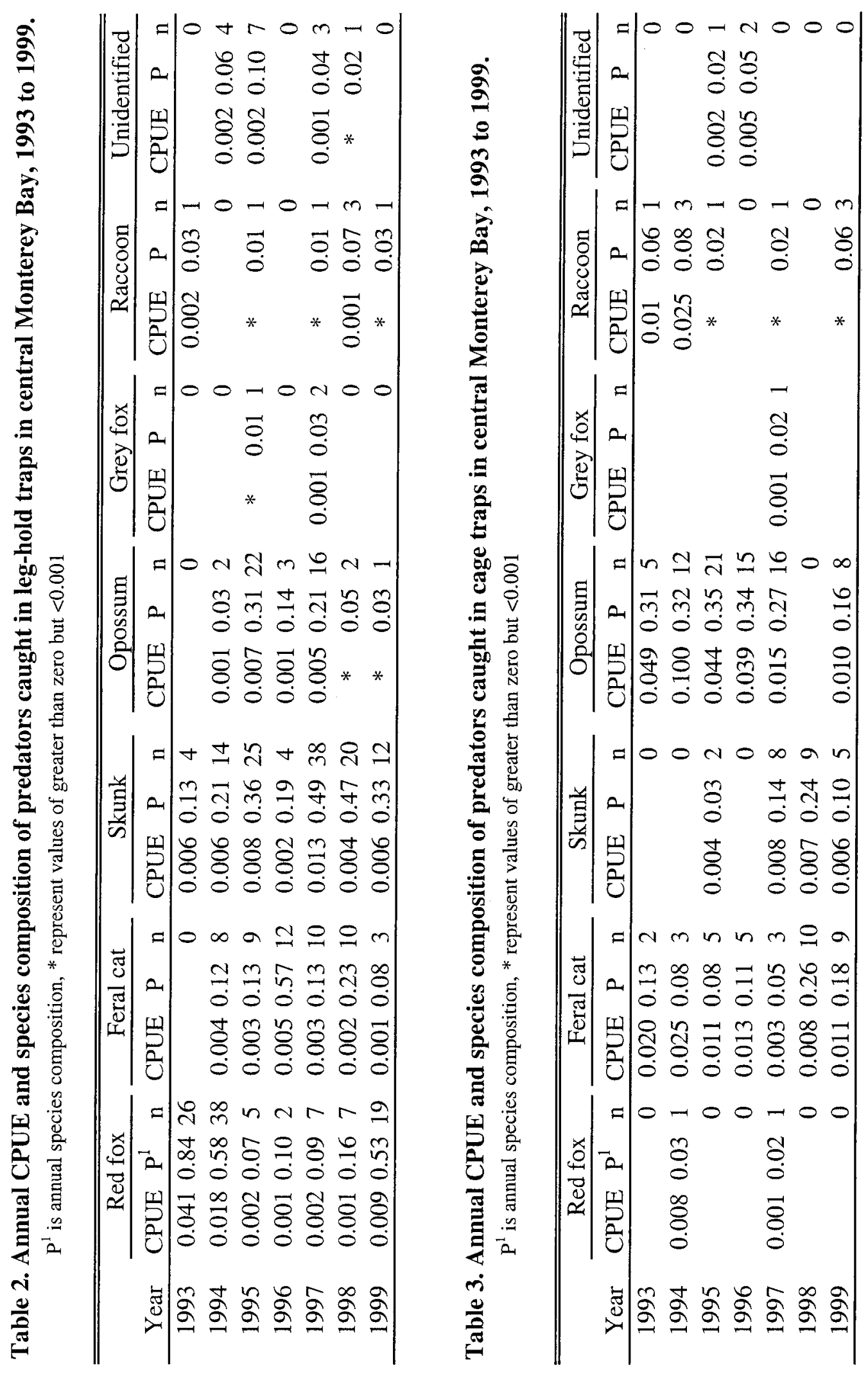


Table 4. Renkonen Percent Similarity Index for annual array of predators caught in leg-hold traps in central Monterey Bay, 1993 to 1999.

$*$ indicates values of $<30 \%$ similarity

\begin{tabular}{ccccccc}
\hline \hline Year & 1994 & 1995 & 1996 & 1997 & 1998 & 1999 \\
\hline 1993 & 0.705 & $0.215^{*}$ & $0.224^{*}$ & $0.233^{*}$ & 0.324 & 0.685 \\
1994 & $\mathrm{X}$ & 0.496 & 0.437 & 0.494 & 0.550 & 0.889 \\
1995 & & $\mathrm{X}$ & 0.533 & 0.892 & 0.641 & 0.530 \\
1996 & & & $\mathrm{X}$ & 0.554 & 0.565 & 0.397 \\
1997 & & & & $\mathrm{X}$ & 0.769 & 0.548 \\
1998 & & & & & $\mathrm{X}$ & 0.635 \\
1999 & & & & & & $\mathrm{X}$
\end{tabular}




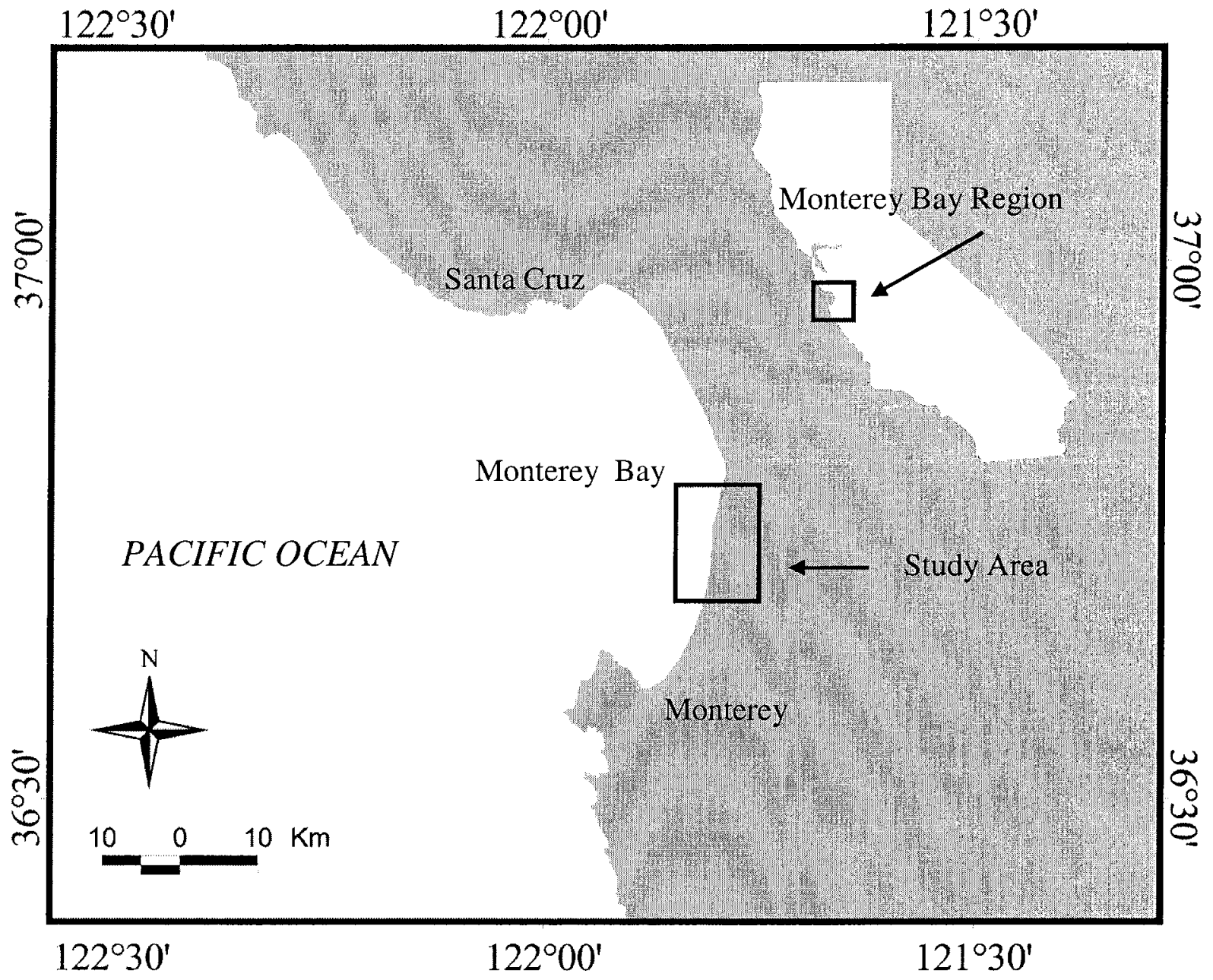

Figure 1. Study area (larger boxed region), coastal beaches in central Monterey Bay, California. 


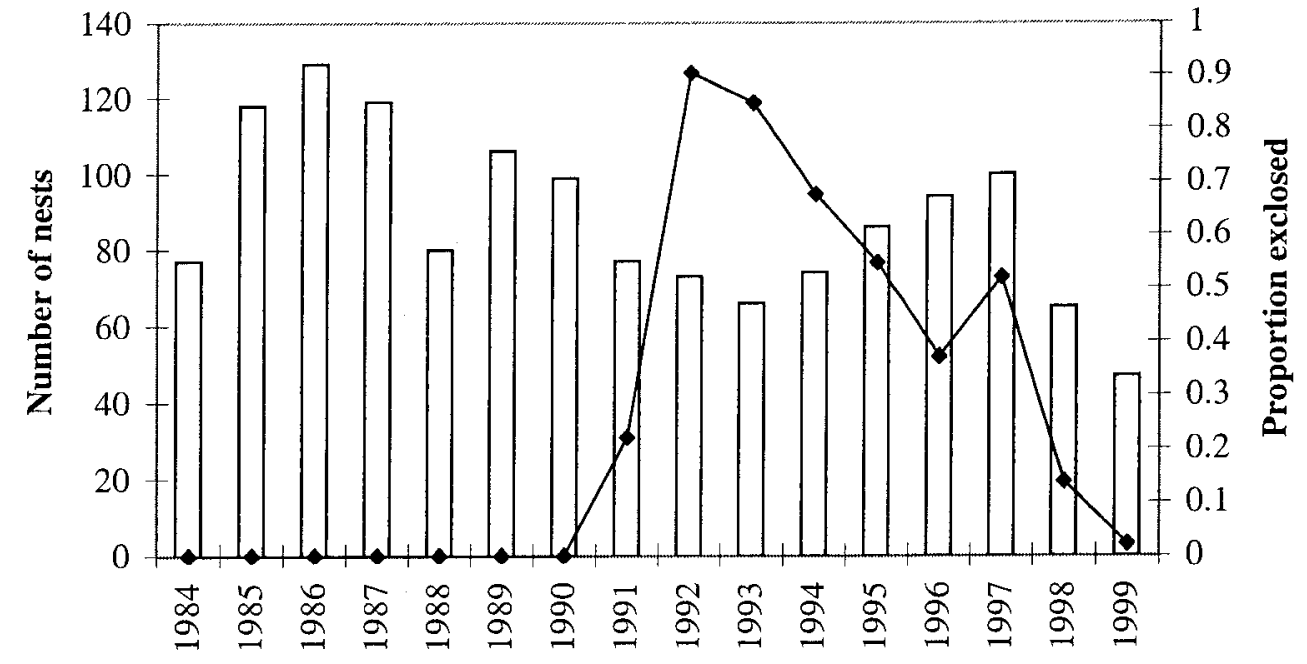

Figure 2. Number of snowy plover nests (bars) and proportion exclosed (line) in central Monterey Bay, 1984-1999. Predators were removed from 1993 to 1999. 


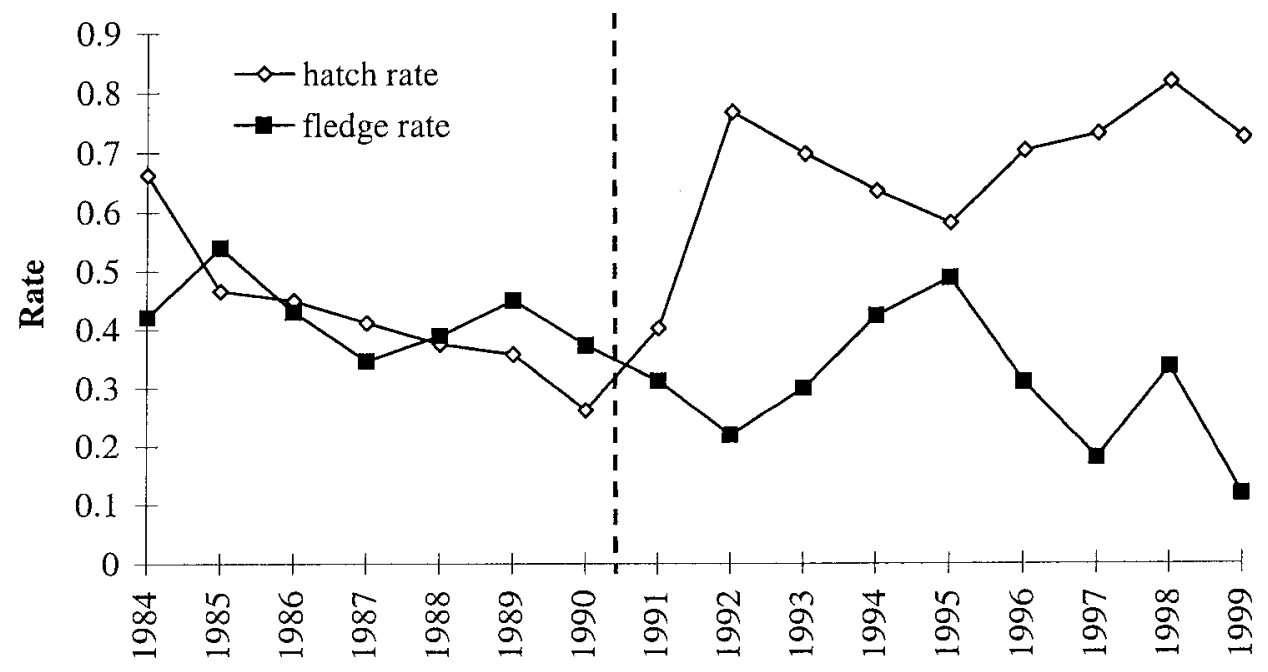

Figure 3. Hatch rate and fledge rate of snowy plovers in central Monterey Bay, 1984-1999. Dashed line indicates boundary between pre-management and management phases.

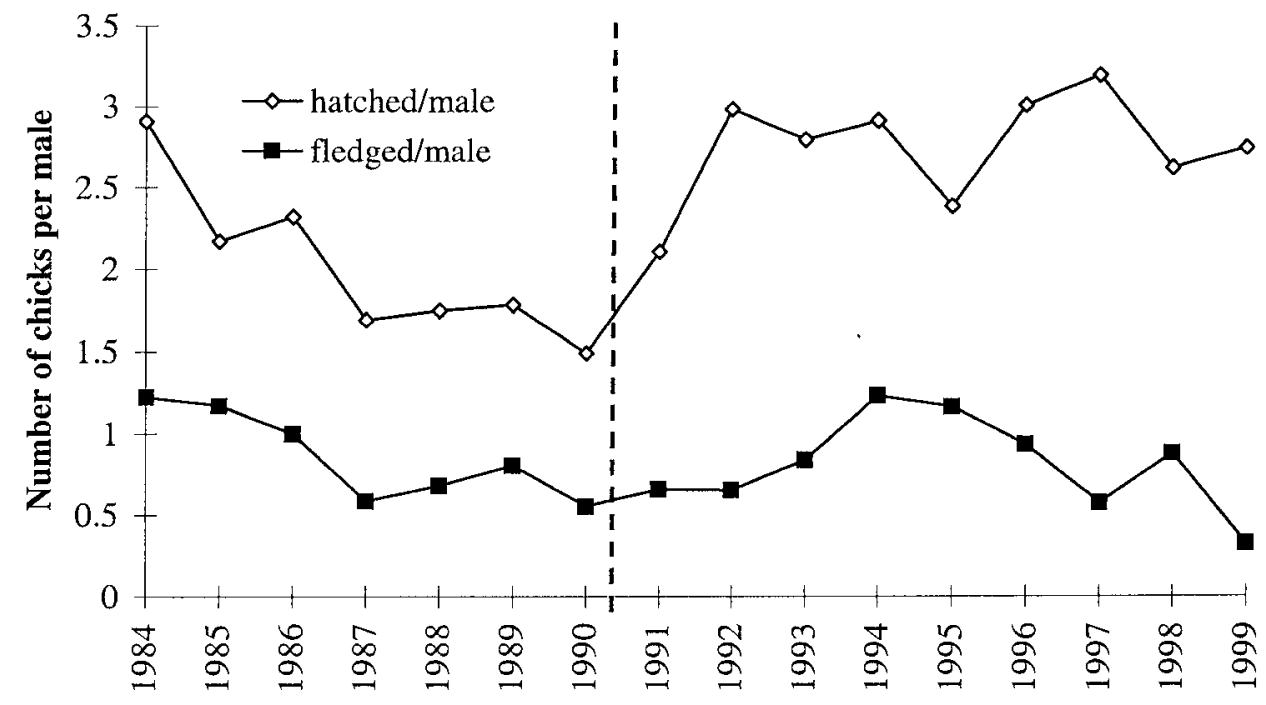

Figure 4. Number of snowy plover chicks hatched per male and fledged per male in central Monterey Bay, 1984-1999. Dashed line indicates boundary between pre-management and management phases. 


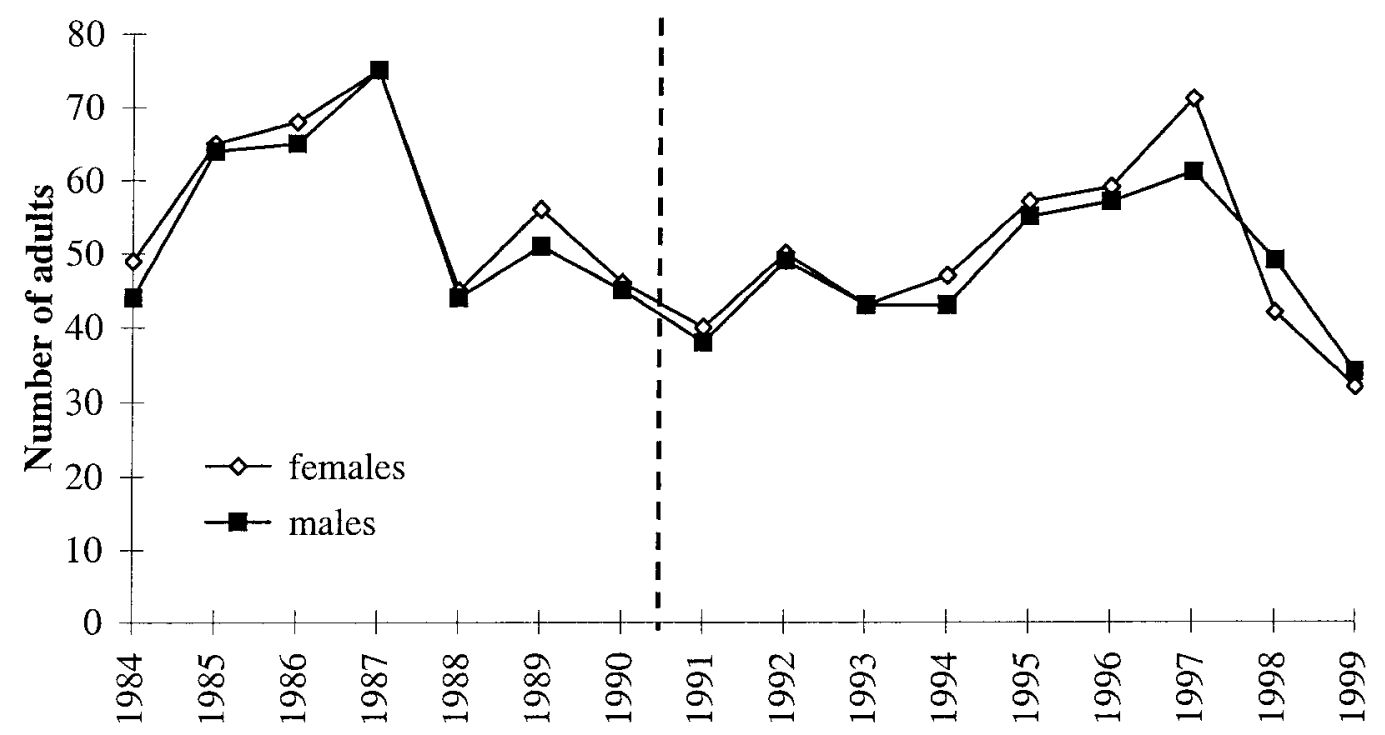

Figure 5. Number of breeding adult male and female snowy plovers in central Monterey Bay, 1984-1999. Dashed line indicates boundary between pre-management and management phases. 


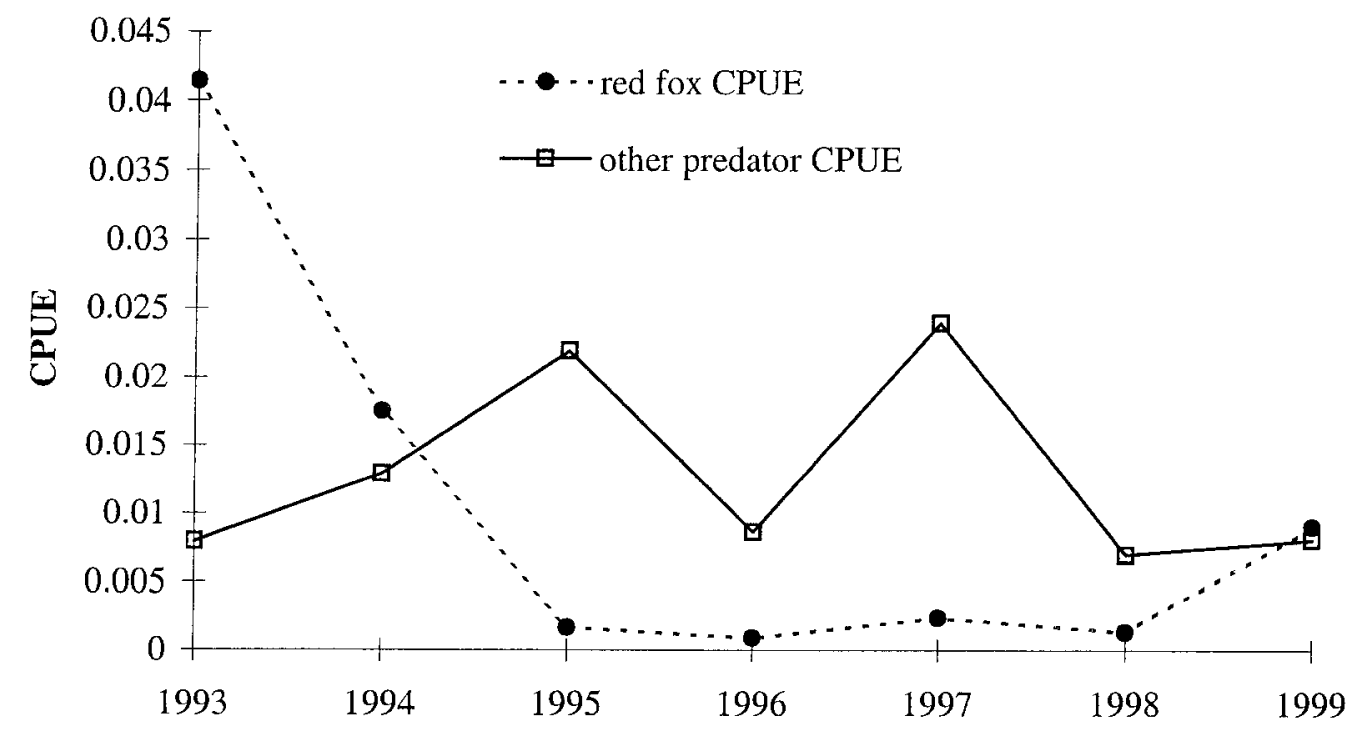

Figure 6. CPUE of red fox and other predators caught in leg-hold traps in central Monterey Bay, 1993-1999. See Table 2 for a list of other predators.

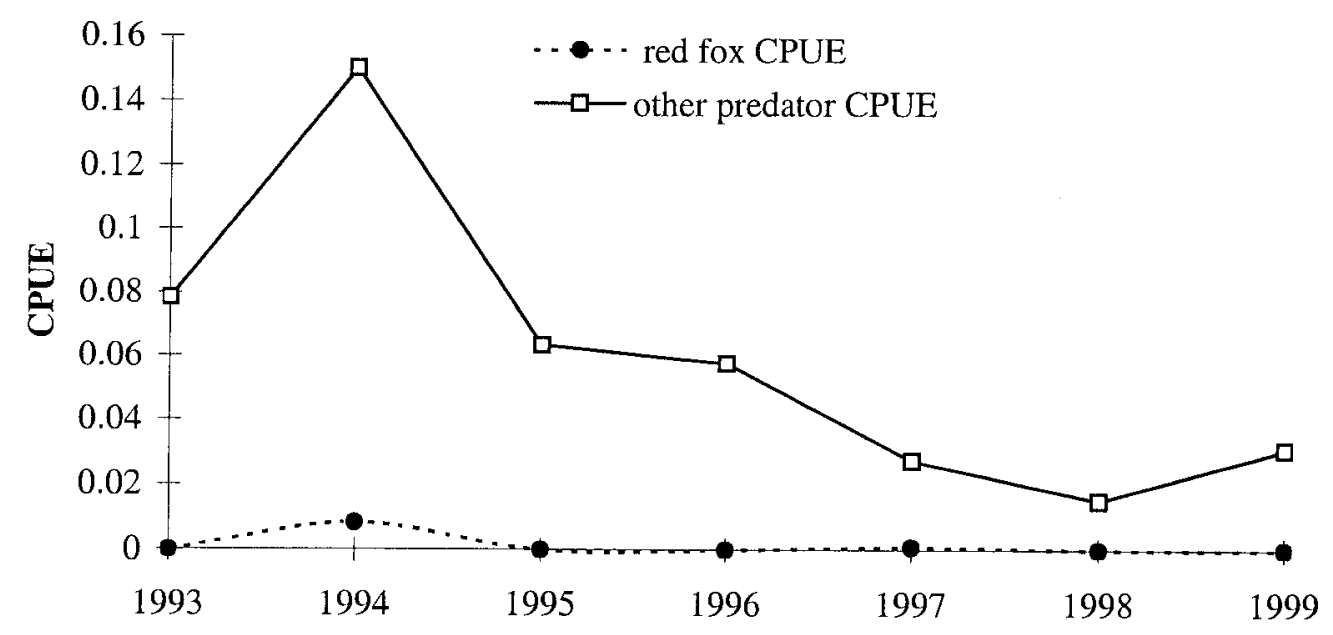

Figure 7. CPUE of red fox and other predators caught in cage traps in central Monterey Bay, 1993-1999. See Table 3 for a list of other predators. 


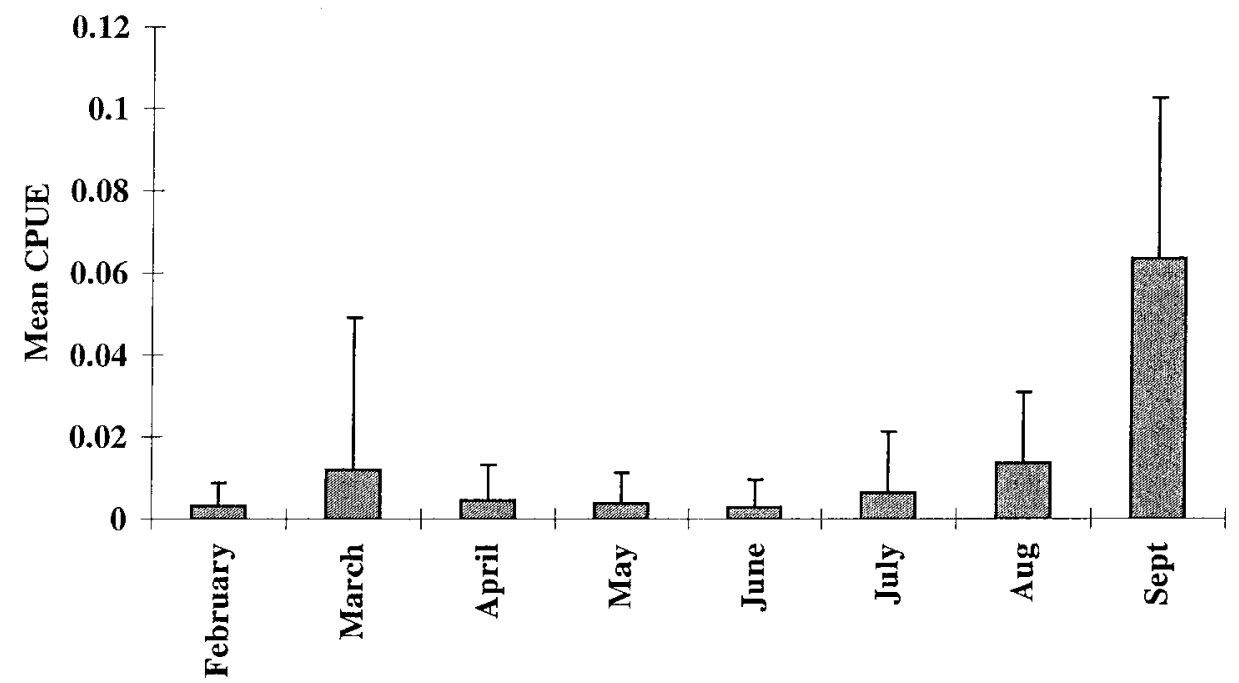

Figure 8. Mean monthly CPUE of red fox caught in leg-hold traps in central Monterey Bay, 1993-1999. Error bars indicate standard deviation. 